\title{
Marketing Efficiency between Traditional and Modern Supply Chains of Fruits and Vegetables
}

\author{
Jaiprakash Bisen ${ }^{1}$, R.K. Patel ${ }^{2}$, K.K. Kundu² and Sanjay² \\ ${ }^{1}$ Division of Agricultural Economics, IARI, Pusa, New Delhi, India \\ ${ }^{2}$ Department of Agricultural Economics, CCS Haryana Agricultural University, Hisar, Haryana, India \\ *Corresponding author: sanjaybhyan@gmail.com
}

\begin{abstract}
The upcoming modern retail store for fruits and vegetables have a very pronounced impact on its market and have led to the emergence of new supply chains all across the country. The present study was undertaken in Hisar and Karnal district of Haryana to compare the marketing efficiency of fruits and vegetables supply chain. For the present study a sample size of 200 respondents and two supply chains for fruits and vegetables were chosen purposefully. The findings of the study revealed that the modern supply chain (MSC) for fruits and vegetables was more efficient than the traditional supply chain (TSC) for both the fruits and vegetables. The percentage of physical losses at traditional supply chain was found to be 20.6 per cent while in the modern supply chain it was only 6.66 per cent. The index of marketing efficiency was found to be 1.06 in MSC of vegetables as against the 0.77 in TSC, whereas for fruits the marketing efficiency index was found to be 2.49 in MSC as compared to 1.99 in TSC. The share of the producer in consumer's rupee was found to be 52 and 43 per cent in MSC and TSC respectively for vegetables. However, producers share in consumer's rupee was found to be 70 and 66 per cent in MSC and TSC of fruits. The major factors contributing to the efficiency of MSC were found to be a short length of the supply chain, packaging and less physical loss in the MSC.
\end{abstract}

Keywords: Traditional Supply Chain, Modern Supply Chain, Index of Marketing Efficiency, Producer's share in Consumer's rupee

Economic reform (1991) and WTO regime (1995) are primarily responsible for orienting the Indian food markets towards more efficient ones. In one hand globalisation has led Indian agro-exporters to access the global market easily and on another hand it has introduced foreign trade culture into Indian marketplace. As a result of it, many food giants are exploring and accessing Indian market which brings tremendous changes in the taste of Indian consumers and influencing the behaviour of food traders in the Indian market. Haryana is no more an exception to experience the presence of modern retailers with professionally managed and sophisticated retail stores. The high per capita income (Sixth in 2013-14), well-connected cities and the close proximity of state to the national capital are few of the major factors which have led to quicker penetration of modern retailers into
Haryana. Since many of the modern retail stores are also dealing with fresh fruits and vegetables; it has given birth to the new supply chain of fruits and vegetables parallel to the traditional supply chain in the state. The growing preference of consumers (particularly upper middle and upper class) for the modern retail stores in the state has posed an important question for researchers and policy makers- Are the modern supply chains are operating more efficiently than already existing traditional supply chain in Haryana state? To answer the question the study was conducted with an objective of comparing the marketing efficiency of traditional and modern supply chain of fruits and vegetables in Haryana state.

Several studies have been conducted in different parts of India to compare the efficiency of the traditional as well as modern supply chain of 
vegetables and fruits. The majority of the studies have reported that the producers associated with emerging marketing channels (organised retail chains) have been experiencing more advantage than the traditional supply chain. The producers contracted by modern retail chains receive higher prices (Dhananjaya and Rao, 2009; Alam and Verma, 2007), higher net profits (Mangala and Chengappa, 2008; Birthal et al. 2005) and incur lower transaction costs (Joseph et al. 2008). Dastagiri et al. (2013) in their study on vegetables have estimated the index of marketing efficiency for vegetables under study for different channels of vegetables reported thatthe producer's share in consumer rupee was highest in Punjab, Tamil Nadu and Manipur because of direct marketing of vegetables exist in these states. The study also revealed that the highest marketing efficiency was found in direct marketing channels. Aparna and Hanumantaiah (2012) have revealed that the net price received by the producers and producer's share in consumer's rupee was higher in supermarket channel than in traditional channels. Thus, the supermarket channel has been found more efficient than the traditional channels. Dastagiri et al. (2012) have found that the producers in the most of the states preferred traditional marketing channels and Punjab is the only state which is practicing direct marketing models and followed by Karnataka through Horticultural Producer's Co-operative Marketing and Processing Society Limited (HOPCOMS). The direct market models were found to be the best because the producer share in consumer rupee was $100 \%$ and it has eliminated middlemen completely. Singh (2011) has revealed that the net revenue of the producer for selected vegetables on an average was higher by17, 134, 17,45, 50, and 57percent for carrot, bottle gourd, green chilli, onion, bhendi, and musk melon respectively, in the Mother Dairy as compare to traditional market except for cauliflower. In short the direct procurement of the produce has enhanced the producer's revenue. Sidhu (2010) in his report to NCAP has reported that for okra the marketing efficiency in emerging supply chain (2.35) was high as compared to traditional supply chain (2.15) due to less number of intermediaries in the former supply chain. Thus, the length of the supply chain has a negative impact on the efficiency of the marketing channel.

\section{Database and Methodology}

The study is based on primary data from Hisar \& Karnal district of Haryana. The data was collected from producers, commission agent cum wholesaler; retailers and consumers on different aspects from the traditional as well as modern supply chain of fruits and vegetables. The two channels and two districts were chosen purposively by taking into account the time and financial constraint. The fruits and vegetables were chosen from the crops from the district agricultural plan of the concerned districts.

Multistage random sampling was undertaken to select respondents from the study region. Total 60 producers (30 from each district) in traditional supply chain, 10 producers (5 from each district) in modern supply chain, 40 market intermediaries (10 in each district under each supply chain) and 90 consumers (30under modern supply chain in each district and 15under traditional supply chain in each district) were selected. Thus, the sample size was of 200. The number of producers under each supply chain was chosen based on the availability of the producers supplying fruits and vegetables to each supply chain.

To arrive at the results- price spread, producer's share in the consumer rupee, marketing margin and marketing efficiency index were calculated.

(a) Price Spread is the difference between the price paid by the consumer and price received by the producer for an equivalent quantity of farm produce.

(b) Marketing Margin of a Middleman is the difference between the receipts (sale price) and total payments (cost + purchase price) of the middlemen ( $\mathrm{i}^{\text {th }}$ agency).

(c) Producer's Share in Consumer's Rupee is the price received by the producer $\left(\mathrm{P}_{\mathrm{f}}\right)$ expressed as a percentage of the retail price (i.e. the price paid by the consumer, $\mathrm{P}_{\mathrm{r}}$ ). The producer's share in the consumer's rupee $\left(\mathrm{P}_{\mathrm{s}}\right)$ may be expressed as:

$\mathrm{P}_{\mathrm{s}}=\left(\mathrm{P}_{\mathrm{f}} / \mathrm{P}_{\mathrm{r}}\right) \times 100$

(d) Marketing Efficiency Index: The ratio of the net price received by the producer/ producer to the total marketing cost and total net margins of intermediaries as suggested by Acharya and Agarwal (1999) 
$\mathrm{ME}=\mathrm{FP} /(\mathrm{MC}+\mathrm{MM})$

Where,

\section{ME: Marketing efficiency}

FP: Net price received by the producer-seller

MC: Total marketing cost

MM: Net marketing margin

\section{RESULTS AND DISCUSSION}

The two major supply chains which are given below for vegetables and fruits were chosen in the light of objectives and constraints of the study:

\section{Traditional Supply Chain (TSC)}

\section{Producer $\rightarrow$ Commission agent cum-wholesaler \\ $\rightarrow$ Retailer $\rightarrow$ Consumer}

Under the TSC of fruits and vegetables, the producers are arriving in the market either in the late night or early hours in the morning due to lack of adequate market infrastructure and perishability of produce and sell their produce to the commission agent cum wholesaler in the wholesale market. The commission agents are found to play a dual role of ahartiya and wholesaler. These, wholesaler cum commission agent procured at a very nominal price from the producers and sold it to retailers after adding their commission (5\%), cost (Market fee- $1 \%$ and labour charges- $2 \%$ and other costs) and profit $(2 \%)$. The produce was sold to the retailers after around 8:00 am to 9:00 am. Retailers were found to sell their produce either by sitting in front of the wholesaler's shop or as per their convenience in rehries (Hath Thela). The retailer was the man in the traditional supply chain who accounted for maximum margin in whole supply chain.

\section{Modern Supply Chain (MSC)}

\section{Producers $\rightarrow$ Retail Outlets $\rightarrow$ Consumers}

It was found that in the study region the existed modern retail outlets did not have any permanent contract with producers. They procured directly from the producers in the market. They also carried their vehicle to the market in early hours of the day and participated in the bidding process for fruits and vegetables. They procured only superior quality produce (Usually, fresh with bright colour, uniform shape etc.) from producers leaving aside rest of the produce of the producers. For this, they paid a premium price to the producers as compared to the price paid by commission agent cum wholesaler in the traditional supply chain. These, produce once purchased, taken to the retail outlets where they were cleaned, packaged (according to the vegetables and fruits) and then only kept for sale to the consumers.

\section{(a) Packaging materials used in different supply chains}

The major materials used for packaging of fruits and vegetables under traditional and modern supply chain formats in the study area were found to be polyethene bags, palli, gunny bags and plastic crates. The packaging materials for produce under the modern supply chain were found to be biased towards plastic crates or paper carton however in the traditional supply chain the response were mixed. It was also found that only in modern formats of the supply chain of fruits and vegetables, proper packaging of produce got due importance. Table $1 \& 2$ shows the materials used for packaging fruits and vegetables in Hisar \& Karnal district respectively.

\section{(b) Physical losses in traditional and modern supply chains}

At the aggregate level, the total quantity of fruits and vegetable handled per day in the traditional supply chain was found to be $7544.000 \mathrm{~kg}$. Out of the total quantity handled per day, 20.91 per cent $(287.168 \mathrm{~kg})$ of fruits and vegetable were lost per day. However, in the modern supply chain at the aggregate level average quantity of fruits and vegetable handled per day was found to be $36.767 \mathrm{~kg}$. Out of which 6.66 per cent of fruits and vegetable were wasted, which was equal to 1.120 $\mathrm{kg}$ of fruits and vegetable (Table 3).

\section{Comparison of producer's share in consumer rupee, marketing efficiency and price spread in the traditional and modern supply chain}

(A) Fruits: It was found that the supply chain for fruits was relatively more efficient as compared to the vegetable supply chain. The main reason for more efficient fruit supply chain was because of relatively lesser physical losses of fruits as compared to vegetables and a higher share of producers in 
Table 1: Packaging material used by the producers in both supply chains of fruits and vegetables in Hisar district

\begin{tabular}{|c|c|c|c|c|c|c|c|c|c|}
\hline \multirow{2}{*}{$\begin{array}{l}\text { Sl. } \\
\text { No. }\end{array}$} & \multirow{2}{*}{$\begin{array}{c}\text { Fruits/ } \\
\text { vegetables }\end{array}$} & \multicolumn{4}{|c|}{ TSC $(n=30)$} & \multicolumn{4}{|c|}{ MSC $(n=05)$} \\
\hline & & GB/Palli & Loose & PB/PC & PCR & GB/ Palli & Loose & PB/PC & PCR \\
\hline 1 & Guava & $9(30)$ & - & $21(70)$ & - & - & - & - & $5(100)$ \\
\hline 3 & Cauliflower & $3(10)$ & - & $27(90)$ & - & - & - & $3(60)$ & $2(40)$ \\
\hline 4 & Carrot & $30(100)$ & - & - & - & $1(20)$ & - & - & $4(80)$ \\
\hline
\end{tabular}

Figures in parentheses show the percentage of a total number of respondents; Abbreviations: TSC: Traditional supply chain, MSC: Modern supply chain, GB: gunny bag, PB: Polythene bag, PC: Paper carton, PCR: Plastic crates.

Table 2: Packaging material used by the producers in both supply chains of fruits and vegetables in Karnal district

\begin{tabular}{cccccccccc}
\hline S1. & Fruits/ & \multicolumn{4}{c}{ TSC (n=30) } & \multicolumn{4}{c}{ MSC (n=05) } \\
No. & vegetables & GB/ Palli & Loose & PB/PC & PCR & GB/ Palli & Loose & PB/PC & PCR \\
\hline 1 & Guava & $21(70)$ & - & $9(30)$ & - & - & - & - & $5(100)$ \\
2 & Mango & $3(10)$ & $9(30)$ & $15(50)$ & $3(10)$ & - & - & - & $5(100)$ \\
3 & Tomato & - & - & $15(50)$ & $15(50)$ & - & - & - & $5(100)$ \\
4 & Cauliflower & $24(80)$ & $6(20)$ & - & - & - & - & $4(80)$ & $1(20)$ \\
5 & Radish & $30(100)$ & - & - & - & $1(20)$ & - & $1(20)$ & $3(60)$ \\
6 & Potato & $30(100)$ & - & - & - & $4(80)$ & - & - & $1(20)$ \\
\hline
\end{tabular}

Figures in parenthesis show percentage of total number of respondents (\%); Abbreviations: TSC: Traditional supply chain, MSC: Modern supply chain, GB: gunny bag, PB: Polythene bag, PC: Paper carton, PCR: Plastic crates.

Table 3: Average physical losses at aggregate level in traditional and modern supply chains

\begin{tabular}{|c|c|c|c|c|c|c|c|}
\hline \multirow{3}{*}{ S1. No. } & \multirow{3}{*}{ Particulars } & \multicolumn{6}{|c|}{ Aggregate level } \\
\hline & & \multicolumn{3}{|c|}{ TSC } & \multicolumn{3}{|c|}{ MSC } \\
\hline & & TQH (kg) & TQL (kg) & W (\%) & TQH (kg) & TQL (kg) & W (\%) \\
\hline \multirow[t]{2}{*}{2} & Retail level & 61.750 & 3.841 & 12.87 & 36.767 & 1.120 & 6.66 \\
\hline & Total & 7544.000 & 287.168 & 20.91 & 36.767 & 1.120 & 6.66 \\
\hline
\end{tabular}

TSC: Traditional supply chain, MSC: Modern supply chain, TQH-Total quantity handled/ day (kg), TQL-Total quantity loss/day (kg), W- \% of wastage to total quantity handled.

consumer rupee. The other reasons for higher efficiency of fruit supply chain were found to be relatively good packaging and proper handling of fruits.

Table 4 showed that under traditional supply chain consumers have paid an average price of ₹ 30.07 for per $\mathrm{kg}$ of fruits while the producers have received net returns of ₹ 20.41 per $\mathrm{kg}$ of fruits sold. The average marketing cost per $\mathrm{kg}$ of fruits was found to be ₹ 3.67 while net marketing margin per $\mathrm{kg}$ of fruit was found out to be ₹ 6.30 . The price spread was ₹ 9.67; producer's share in consumer rupee was
66.16 percent and index of marketing efficiency was estimated to be 1.99 .

However, under modern supply chain producers have received average net returns of ₹ 24.75 per $\mathrm{kg}$ of fruits which accounted for 70.08 percent share of producers in the consumer's rupee. The average marketing cost per $\mathrm{kg}$ was estimated to be ₹ 6.09 per $\mathrm{kg}$ of fruits which was higher than the per $\mathrm{kg}$ marketing cost in the traditional supply chain. It was because of the fact that the shop rent, electricity bill paid by the modern retailers and wages and salaries of workers and professionals were quite 
higher than these charges in the traditional supply chain. Apart from these, packaging cost was found to be higher in the modern supply chain. The price spread per kg of fruits was found to be ₹ 9.50 which was less than the price spread in the traditional supply chain because of the shorter length of the supply chain, less number of middlemen and higher purchasing price. The index of marketing efficiency was found to be 2.49 which were quite higher than the index of marketing efficiency in the traditional supply chain (1.99).

(B) Vegetables: It is evident from the given below table that, for selling one $\mathrm{kg}$ of vegetable under the traditional supply chain, the marketing cost incurred by producers and market intermediaries was ₹ 2.23; the net marketing margin of all the intermediaries (Usually Wholesaler cum commission agent and retailer) was ₹ 8.53. The producers had received net returns of ₹ 8.15 after selling one $\mathrm{kg}$ of vegetables under traditional supply chain and consumer have paid an average ₹ 18.70 per $\mathrm{kg}$ of vegetables. The price spread in the traditional supply chain was $₹ 10.55$ and producer's share in consumer rupee was found to be 43.20 percent. While the index of marketing margin (as calculated by modified Acharya's method) was found to be 0.77 .

However, under modern supply chain price paid by the consumer per $\mathrm{kg}$ of vegetable was found to be ₹ 20.16, while average marketing cost per $\mathrm{kg}$ of vegetable was quite higher (₹ 4.27) due to the higher cost incurred in packaging; advertisement and propaganda; shop rent; electricity charges; labour charges etc. But, the average net marketing margin under modern supply chain was less than the average net marketing margin in the traditional supply chain (₹ 5.68). It is also evident from the

Table 4: Producer's share in consumer's rupee, price spread and index of marketing efficiency in selected supply chains of fruits

\begin{tabular}{cccccccc}
\hline \multirow{2}{*}{ S1. No. } & \multirow{2}{*}{ Particulars } & \multicolumn{2}{c}{ Hisar } & \multicolumn{2}{c}{ Karnal } & \multicolumn{2}{c}{ Aggregate Average } \\
\cline { 2 - 7 } & & TSC & MSC & TSC & MSC & TSC & MSC \\
\hline 1 & RP (₹/kg) & 21.71 & 25 & 38.43 & 43.5 & 30.07 & 34.25 \\
2 & MC (₹/kg) & 3.25 & 5.86 & 4.08 & 6.32 & 3.67 & 6.09 \\
3 & MM (₹/kg) & 5.43 & 3.64 & 7.17 & 3.87 & 6.30 & 3.76 \\
4 & FP (₹/kg) & 13.03 & 15.5 & 27.78 & 34 & 20.41 & 24.75 \\
5 & PS (\%) & 60.02 & 62 & 72.29 & 78.16 & 66.16 & 70.08 \\
6 & MME 4/(2+3) & 1.5 & 1.63 & 2.47 & 3.34 & 1.99 & 2.49 \\
7 & PS (₹/kg) & 8.68 & 9.5 & 10.65 & 9.5 & 9.67 & 9.50 \\
\hline
\end{tabular}

Abbreviations: TSC: Traditional supply chain, MSC: Modern supply chain, RP: Retailers sale price MC: Total Marketing Cost, MM: Total Marketing margins of intermediaries, FP: Net price received by producer, PC: Producer's share in consumer rupee, MME: Index of marketing efficiency, PS: Price spread (RP-FP)

Table 5: Producer's share in consumer's rupee, price spread and index of marketing efficiency in selected supply chains of vegetables

\begin{tabular}{cccccccc}
\hline \multirow{2}{*}{ S1. No. } & \multirow{2}{*}{ Particulars } & \multicolumn{2}{c}{ Hisar } & \multicolumn{3}{c}{ Karnal } & \multicolumn{2}{c}{ Aggregate Average } \\
\cline { 2 - 7 } & & TSC & MSC & TSC & MSC & TSC & MSC \\
\hline 1 & RP (₹ $/ \mathrm{kg})$ & 19.9 & 22 & 17.5 & 18.31 & 18.7 & 20.16 \\
2 & MC (₹/kg) & 2.44 & 4.1 & 2.01 & 4.44 & 2.23 & 4.27 \\
3 & MM (₹/kg) & 7.67 & 5.88 & 9.38 & 5.48 & 8.53 & 5.68 \\
4 & FP (₹/kg) & 9.8 & 12.03 & 6.5 & 8.88 & 8.15 & 10.46 \\
5 & PS (\%) & 49.25 & 54.66 & 37.14 & 48.5 & 43.20 & 51.58 \\
6 & MME 4/(2+3) & 0.97 & 1.21 & 0.57 & 0.9 & 0.77 & 1.05 \\
7 & PS (₹/kg) & 10.1 & 9.97 & 11 & 9.43 & 10.55 & 9.70 \\
\hline
\end{tabular}

Abbreviations: TSC: Traditional supply chain, Modern supply chain, RP: Retailers sale price MC: Total Marketing Cost, MM: Total Marketing margins of intermediaries, FP: Net price received by producer, PC: Producer's share in consumer rupee, MME: Index of marketing efficiency, PS: Price spread (RP-FP) 
given table that producer's share in consumer rupee was found to be higher $(51.58 \%)$ in the modern supply chain; price spread was ₹ 9.70 which was lower than price spread in traditional supply chain and index of marketing efficiency was estimated to be 1.05 which was higher than the index of marketing efficiency of the traditional supply chain (0.77)

\section{CONCLUSION}

The study revealed that price spread was less in the modern supply chain for fruits and vegetables. Whereas, producers share in consumer rupee and index of marketing efficiency were higher in the modern supply chain for same as compared to the traditional supply chain. Thus, the modern supply chain of fruits and vegetables were found to be more efficient in their operation as compared to the traditional supply chain in Haryana. Since these modern retail outlets serve mostly to the highincome strata and supplies superior quality of fresh fruits and vegetables. It could be inferred from the study that less efficiency of the traditional supply chain of vegetables and fruits were attributed to a number of marketing intermediaries, longer supply chain, more physical losses and lack of integration among the producers. Based on the findings of the study, following recommendations can be put forward:

Producers should adopt the modern packaging materials for packaging the produce. Awareness programmes must be encouraged for eco-friendly, biodegradable, low-cost packaging materials as alternative sources for fruits and vegetables for discouraging the use of polythene bags by producers, middlemen and modern retail outlets by agencies like Indian Institute of Packaging (IIP) in the market.

The producers must come together to form a cooperative marketing society which will take care of their current as well as future needs and helps to reduce per head charges for various cost incurred by the producers individually for gaining better bargaining power for more profit/ price realization.

The Government should promote the direct marketing channels via implementation and proper regulation of APMC Act promulgated by the central government.
The government must promote the infrastructural development of various fruits and vegetable markets in the state by encouraging public-private partnership in market infrastructural development and linking producers with modern supply chains.

Strengthen the existing cold storage and encourage new cold chain networks in the state via proper incentives to the investors and the location, storage charges, storage capacities and other necessary information regarding cold storages should be made available to the producers in the market as fruits and vegetables being the highly perishable commodities in both the supply chains.

The different stakeholders in the traditional supply chain should be integrated well to meet the desires of different sections of society at least possible cost and minimum wastage through much better handling of produce in both the supply chains.

The length of the supply chains for fruits and vegetables must be reduced to the maximum possible extent by encouraging the direct market channel and the persons, who may lose a job because of disintermediation, should be engaged in other market functions like grading, consolidations, packaging, processing etc.

\section{REFERENCES}

Acharya, S.S. and Agarwal, N.L. 1998. Marketing functions. In: Agricultural Marketing in India. New Delhi: Oxford and IBH, pp. 386-387.

Alam, G. and Verma, D. 2007. Connecting Small-scale Producers with Dynamic Markets: A Case Study of a Successful Supply Chain in Uttarakhand. Centre for Sustainable Development, Dehradun.

Aparna B. and Hanumanthaiah, C.V. 2012. Are Supermarket Supply Channels More Efficient than Traditional Market Channels? Agricultural Economics Research Review, 25(02): 309-316.

Birthal, P.S., Joshi, P.K. and Gulati, A. 2005. Vertical Coordination in High-value Food Commodities: Implications for Smallholders. MTID Discussion Paper No. 85, IFPRI, Washington.

Dastagiri, M.B., Ramesh Chand, T.K. Immanuelraj, C.V. Hanumanthaiah, P. Paramsivam, R.S. Sidhu, M. Sudha, Subhasis Mandal, Basantha Singh, Khem Chand, B. Ganesh Kumar 2013. Indian vegetables: production trends, marketing efficiency, and export competitiveness. American Journal of Agriculture and Forestry, 1(1): 1-11

Dhananjaya, B.N. and Rao A.U. 2009. Namdhari Fresh Limited, In:Inclusive Value Chains in India - Linkingthe Smallest Producers at Modern Markets, Ed: M. Harper.World Scientific, Singapore, Case study 1, Chapter 3, pp. 26-41. 
Joseph, M., Soundararajan, N., Gupta, M. and Sahu, S. 2008. Impact of Organized Retailing on the Unorganized Sector. Indian Council for Research on International Economic Relations (ICRIER), New Delhi.

M.B. Dastagiri and Immanuelraj, T.K. 2012. Supermarket Supply Chains in Horticulture in India: The Novel Marketing Models, Effects and Policies" Agrotechnol 2012, S11 http://dx.doi.org/10.4172/2168 9881.S11-001

Mangala, K.P. and Chengappa, P.G. 2008. A novel agribusiness model for backward linkages with producers: A case of food retail chain. Agricultural Economics Research Review, 21(Conference Number): 363370.
Sidhu, R.S., Sidhu, M.S. and Singh, J.M. 2010. Estimation of Marketing Efficiency of Horticultural Commodities under Different Supply Chains in India. National Centre for Agricultural Economics and Policy Research New Delhi (India).

Singh, Jitender 2011. Impact of organized retail chains on revenue of producer (a case study of mother dairy centres in Haryana) - Department of Industrial Policy and Promotion, Ministry of Commerce $\mathcal{E}$ Industry, India. 
